\title{
Business Rescue and Insolvency Regulation and Practice In Nigeria: The Imperatives of Globalization
}

\author{
Osaretin Kayode Omoregie \\ Lagos Business School, \\ Pan-Atlantic University Lagos, Nigeria
}

\begin{abstract}
Business rescue and insolvency regulation and practice is critical to economic development. This is especially true in the light of the unintended consequences of globalisation that may result in economics shocks and business failures. This paper argues that countries with robust business rescue and insolvency laws and practices are better able to manage the adverse impact of local and global economic shocks, attract more foreign investments and achieve faster and even development. Nigeria can benefit from reforms in business rescue and insolvency by benchmarking the reform and practice initiatives of the more advanced countries within and outside Africa. This paper makes some recommendations in this regard.
\end{abstract}

Key Words: Business rescue practitioner; Globalisation; Cash flow insolvency; Balance sheet insolvency; Receiver manager; Business failure; Insolvency; Bankruptcy

\section{INTRODUCTION}

Improving economic growth and development in an increasingly globalized world is an ongoing challenge for developing economies, including Nigeria. The World Bank, economic development researchers and policy makers have identified policies aimed at improving economic diversification, employment generation, sustainable infrastructure development, technology innovation, adoption and transfer, and foreign direct investment (FDI) inflows as critical to this effort. Globalization has brought about the internationalization of businesses, increased international trade, cross-border flow of credit, and the inevitability of some business failures and insolvencies (Okoye \& Nwaigwe, 2015; Barnard, 2016; Omoregie, 2017). The institution of robust and efficient insolvency and business rescue practice regimes is thus another important tool for improving the prospects of development in Nigeria.

\section{Meaning of Insolvency}

Insolvency is a situation where there is a temporary or sustained reduction in the liquidity and cash flow of a business such that the company is not able to meet its financial obligations to its creditors. (Idigbe, 2011; Okolo, 2015; Nigam \& Boughanmi, 2017; Omoregie, 2017). While the exact procedure will vary based on the legal rules in the relevant jurisdiction, and the specific context of each case, the general statutory provisions is that where a creditor(s) brings a proceeding against an insolvent borrower, and the court determines that the borrower is not able to repay his indebtedness, such a firm / debtor will be declared insolvent or bankrupt and should be liquidated under the supervision of a court appointed liquidator, and the proceeds from the liquidation of the firms' assets will be distributed among the creditors in the order of priority of their security, in settlement of outstanding obligations. Business rescue laws have been put in place in some jurisdiction (e.g. Chapter Eleven provisions in the USA), that give insolvent companies some protection from their creditors, thus buying time to workout possible means of returning to a state of solvency and avoid liquidation. 
Two types of insolvency are identified in the literature, cash flow insolvency and balance-sheet insolvency (Idigbe, 2011; Okolo, 2015; Nigam \& Boughanmi, 2017). Cash flow insolvency is a temporary case where a company cannot meet its financial obligations in the short-term, while the balance-sheet insolvency is a situation in which the firm's liabilities are far in excess of its assets (net liability position), with little prospect of reversal of the situation without a recapitalization or restructuring of the operations and capital of the business through some court sanctioned scheme of arrangement (Idigbe, 2011; Okolo, 2015; Omoregie, 2017).

Idigbe (2011) and Okolo (2015) noted that cash flow insolvency may very often be resolved by means of business rescue intervention. The premature declaration of a company as insolvent and incapable of being "rescued", may lead to unwarranted liquidation proceedings with attendant costs to the creditor(s) and debtor alike, and damage to the economy and society at large (Nigam \& Boughanmi, 2017; Epeoglou, 2017; Omoregie, 2017; Okolo, 2015; Idigbe, 2011). Thus, the absence of robust business rescue and insolvency regimes and frameworks in an economy usually leads to premature winding-up of businesses, adds to financial and social losses and ultimately undermines economic growth (Epeoglou, 2017).

\section{Meaning of Business Rescue}

Modern business rescue and reorganization is premised on the logic that an enterprise not only has substantial value as a going concern, but its going concern value exceeds its liquidation value (Smith, 1999; Fromes et al. 2000; Nigam \& Boughanmi, 2017). Business rescue according to Fromes et al. (2000) involves the process where the management and resolution of insolvency is taken out of the formal setting of the jurisprudence of court in favor of an out of court informal resolution.

Xie (2016) on the other hand defined business rescue as a collective strategic rescue proceedings under a legal framework designed to facilitate either the preservation of the distressed company itself and / or the rescue of its underlying business by transferring it to a new owner. This suggests that the business rescue process could take both a formal and informal route, with or without the supervision of the court.

Business rescue, as defined by the (UK) Companies Act 2008, aims to facilitate the rehabilitation of a company that is "financially distressed" by providing for the temporary supervision of the company and management of its affairs, business and property by a Business Rescue Practitioner (BRP), in the belief that the distressed company and its assets can be saved (Brouwer, 2006).

\section{Business Rescue and Insolvency Practitioners}

Since professional work relating to insolvency, liquidation and business rescue requires specialized knowledge and skills, Insolvency Practitioners (IP), or Business Rescue and Insolvency Practitioners (BRIP) have emerged to fill this need. In England, Wales, Scotland and Ireland, the appointment of an Administrator in charge of a business in distress requires that such a person have a license to carry out insolvency related work. For such license to be granted, the person must have passed a Joint Insolvency Examination Board Exam and must have acquired some level of experience before being issued the license. In South Africa, the Companies and Intellectual Property Commission (CIPC) is charged with the responsibility of licensing a Business Rescue Practitioner. However, this is not presently the case in Nigeria. 


\section{Business Rescue - Formal and Informal Arrangements}

Companies in severe financial distress often undergo corporate reconstruction to enable them continue as a going concern rather than go into liquidation. The process of reorganization usually involves raising new capital and persuading creditors / lenders to accept some alternative to or deferment of repayment of debts (Winer et al. 2008; Omoregie 2017; Conradie \& Lamprecht, 2015). Reorganization usually has the objective of giving the delinquent firm time in the short-term to explore the longer-term possibility of restructuring with a view to developing a plan, operating and financial capacities to meet its obligations and continue as a going concern. Reconstruction or reorganization can take the form of a company voluntary arrangement or an administrative order. Company voluntary order or arrangement is basically a legally binding arrangement between a company and its creditors. It usually involves a writeoff of accumulated losses against shareholders' capital and creditor's balances. It therefore results in the alteration of the rights of creditors. To ensure the success of the voluntary arrangement, the support of the creditor is critical.

The objective of a company voluntary arrangement is to ensure that the losses of all claimants on the business is minimized, and that the company can deal with its severe liquidity challenges and continue as a going concern. Such an arrangement works if all the creditors and owners believe that the business (and their claims against the business) is worth more if the entity remains as a going concern than if it is liquidated. In some cases an administrator is appointed to work with the management of the company to achieve a turnaround.

\section{GLOBALIZATION AND ITS IMPLICATIONS FOR BUSINESS RESCUE AND INSOLVENCY PRACTICE}

Globalization is essentially a process of economic integration that has profound social, cultural and political implications. Globalization has resulted in the increasing interaction of people through the growth of the international flow of money, ideas and culture, facilitated by the ease of information exchange, technology and mobility (Okoye \& Nwaigwe, 2015; Ngwube \& Ogbuagu, 2014). We can think of globalization as the "apparent "shrinking" of the world as a result of the increasing pace of integration of people and cultures across international borders, driven by information technology, social media, ease and speed of travel, global trade and internationalization of businesses" (Omoregie, 2017). As economies become more integrated, the risk of global contagions has also increased such that no economy or business across the globe can pretend to be in isolation as failure in one region has the potential to impact others (Barnard, 2016).

With respect to economic growth, a major adverse impact of globalization was manifested in the 2007/2009 global financial crisis (GFC) instigated by the default in the subprime mortgages in the USA. As indicated in Figure 1 below, this led to a sharp drop in the economic growth (GDP) of countries across the globe, resulting in failure of businesses, recessions and personal economic losses. (Ngwube \& Ogbuagu, 2014). This global economic crisis (GFC), which originated in the USA spread to the whole world due to the interconnectedness of economies and financial systems occasioned by globalisation. 


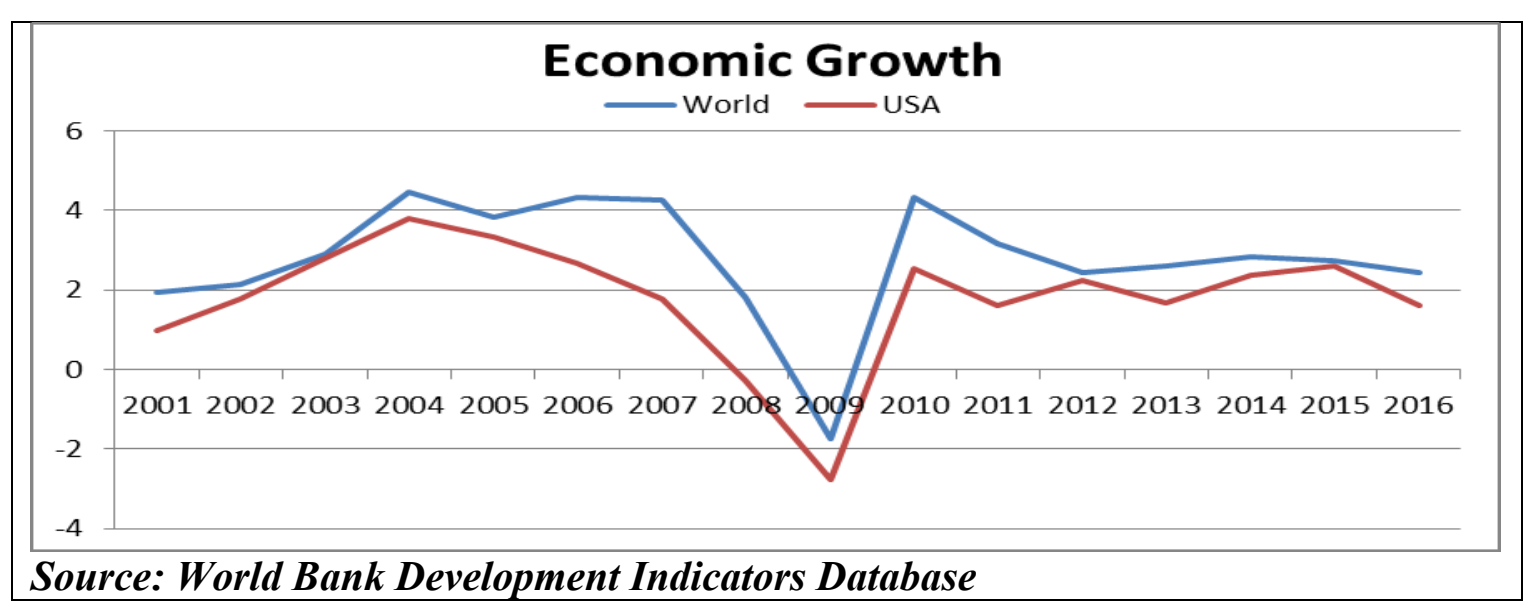

Figure 1: Economic Growth (GDP\%) of the World and the USA

With respect to Nigeria, the global financial crisis was reflected in the downturn in price of oil, a mainstay of the Nigerian economy (accounting for over $90 \%$ of government revenues), and other commodities. Global price of oil dropped from the peak of US $\$ 147$ per barrel in July 2008 to about US $\$ 40$ per barrel in the first quarter of 2009. This constituted a great external shock to Nigerian economy resulting in a drastic drop in foreign earning and government revenue, depletion of foreign reserves and a reversal of the earlier fiscal surpluses to severe deficit (Ngwube \& Ogbuagu, 2014).

A further implication of globalization and the global financial crisis for Nigeria was reflected in the Nigerian Capital Market. By 2005, prior to the global financial crisis, the banking industry dominated the Nigerian Stock Market, accounting for over 50\% of total market capitalization. Bank lending to the business and private sector had risen from 13.17\% of GDP in 2005 to an all-time high of $38.35 \%$ in 2009 . A large percentage of this lending was however not to the real value creating sectors of the economy. They were mainly consumer loans to fund lifestyle improvement and not to fund real economic growth. In addition, over N1.3 trillion ${ }^{1}$ was made available as margin loans to capital market speculators. Some of these speculators invested in bank shares and secured the loans with those same shares.

In April of 2008, following the obvious risk exposure in the banking system, Fitch (an international credit rating company) issued a Bank Systemic Risk Report that rated the resistance of Nigerian banking system to systemic risk as weak. Reports from PriceWaterHouseCoopers (PWC) in February 2009 also showed that the financial health of some banks in Nigeria was weak, with some of them willingly consenting to government intervention in their operations and financial activities. Merrill Lynch (March 2009), reported that the levels of provisioning in Nigerian banks was grossly inadequate after subjecting four Nigerian banks to the earning stress test given the fact that the provision for non-performing loan was $2 \%$ compared to a provision of $11 \%$ which they considered adequate.

By March of 2008, the combined impact of the global financial contagion, falling oil and commodity prices, reduction in global and local credit and exit of foreign institutional investors from the Nigeria capital led to the crash of the capital market (Figure 2). All of these effects are in part a direct impact of globalization.

${ }^{1}$ Equivalent to $\$ 8.7$ billion at exchange rate of $\mathrm{N} 150 / \$ 1$ 


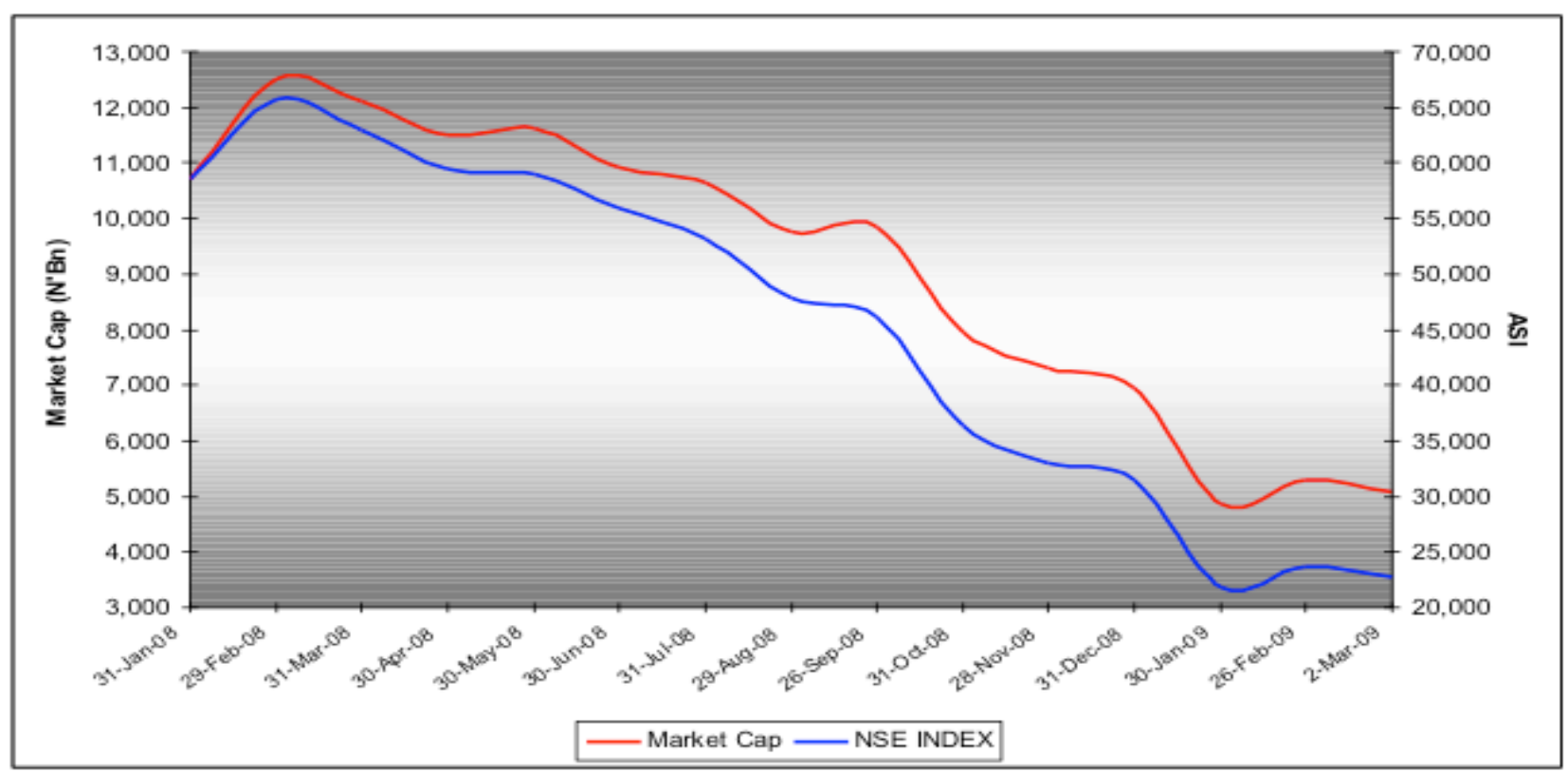

Figure 2: Nigeria Capital Market Capitalization and All Share Index (January 2008 - March 2009). Source: Financial Derivatives, Nigeria

From a peak of NGN12.5 trillion in February 2008, the Nigerian market capitalization dropped to NGN4.48 trillion in March 2009, representing a 64.2\% erosion of value. The All Share Index (ALSI) dropped by 68.5\% from 63,016.56 in March 2008 to 19,851.89 March 2009 (Figure 2). It was inevitable that a number of companies became financially distressed and in need of some form of rescue or reorganization to ensure they can continue as a going concern (Schoenberg, Collier \& Bowman, 2013; Sanni, 2010; Ngwube \& Ogbuagu, 2014).

The banking sector as the dominant sector in the stock exchange was severely hit as the default rate on loans increased to $37.25 \%$ of total loan as shown by the ratio of non-performing loan to gross loan, which reflected the reduced soundness of the banking sector and increased inability of individuals and businesses alike to service their debt obligations. This prompted the CBN to inject over US $\$ 2.72$ billion into susceptible banks to militate against collapse of the financial system (Ngwube \& Ogbuagu, 2014).

The global financial crisis that started in the USA and spread across the globe is a manifestation of some of the direct and unintended consequences of globalization and economic integration. This highlighted the importance of effective modern corporate rescue regulations and regimes (Barnard, 2016). Countries like the USA, UK, Australia, Canada and South Africa that took the lead in putting in place robust business rescue and insolvency regimes and reforms resulted in positive impact on businesses and the economy. Foremost among the countries to implement such reforms with varying degree of sophistication over time are the US by adopting Chapter 11 Bankruptcy Code of 1978, the UK adopting the Insolvency Act of 1986, Canada by adopting Companies' Creditors Arrangement Act (CCAA) and the Bankruptcy and Insolvency Act (BIA) 1985, and Australia by adopting the Australian Corporations Act of 2001. Foremost in Africa is South Africa, which implemented the Chapter 6 of the South African Companies Act (2008/2011).

Nigeria's reactive efforts in this regard culminated in the creation of the Asset Management Company of Nigeria (AMCON). AMCON was established on 19 July 2010, by the AMCON Act, 2010, and has as its mandate the stabilization of the Nigerian financial system through the efficient resolution / acquisition of the non-performing loan assets of Nigerian Banks. As at 
December 2018, AMCON has acquired about 12,537 loans from eligible banks, with a value of over 1.7 Trillion Naira ${ }^{2}$ (Nairametrics, 2019).

\section{The Present Situation of Nigerian: 2009 - 2018}

Following a significant drop in oil prices from a peak of about $\$ 109$ per barrel in mid-2014 to $\$ 45$ per barrel at the end of 2016, developing countries like Nigeria, which is very dependent on oil, revenue, entered a period of slow economic growth (CBN-FSR, 2016:2) ${ }^{3}$. The sharp drop in oil price led to a deterioration in trade balances and a devaluation of the Naira from N197 / $\$ 1: 00$ to $\mathrm{N} 305 / \$ 1.00$ by the close of 2017 . The resultant rise in the cost of production led to a rise in inflation from $8.06 \%$ in 2014 to $15.7 \%$ in 2016, culminating in a recession. Nigeria's growth indicators for the year 2016 showed a negative turn with a growth rate of $-1.54 \%$ down from $6.3 \%$ in 2014.

The banking sector's high volume / high-risk exposure to the energy sector was exacerbated by the massive drop in global oil price and Naira devaluation. As a consequence of these events, asset quality declined, with the ratio of nonperforming loans (NPLs) to gross loans increasing from $2.96 \%$ in 2014 to $15.1 \%$ by the second half of 2016 . Non-performing loans in Nigeria has been reported to have reached an all-time high of over N2.1 trillion (CBN-FSR, 2016:1). The overall impact on the economy was a slowdown of credit to the private sectors, increasing level of unemployment and increase in the level of business insolvencies.

\section{THE NIGERIAN SITUATION AND GLOBAL COMPARISONS}

Following the oil price plunge of 2014 and fall in other commodity price, growth in other major countries of the world has not been impressive (Figure 3). Studies indicate however, that countries with better business rescue and insolvency regimes (as measured by the World Bank Ease of Doing Business Ranking and Ease of Resolving Insolvency Issues Ranking) have been better able to manage the challenges of the global economic vagrancies (Omoregie, 2017, Nigam \& Boughanmi, 2017; Conradie \& Lamprecht, 2015).
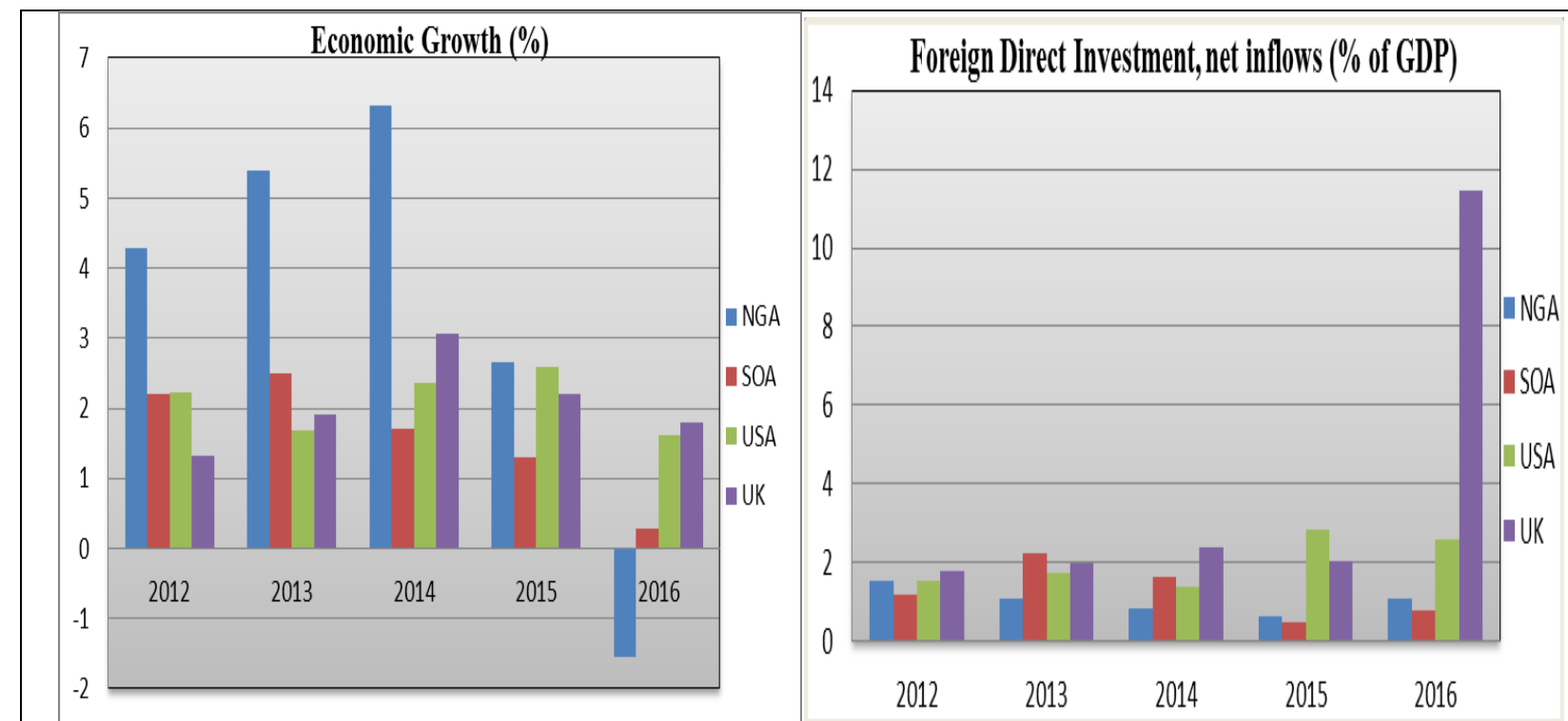

Source: World Bank Development Indicators Database

Figure 3: Comparative Growth and Foreign Direct Investment Inflows of Some Major Economies

2 N1.7 Trillion naira is equivalent to about $\$ 4.7$ Billion dollars at an exchange of N360/\$1
${ }^{3}$ Central Bank of Nigeria (CBN) Financial Stability Report (FRS), 2016; Q2 


\section{Countries With Better Business Rescue and Insolvency Regimes}

According to the World Bank Doing Business data, Nigeria is ranked 145 in the world in terms of Ease of Doing Business and is ranked 21 in terms of ease of doing business in Africa (Table 1). In terms of the time, cost and outcome of resolving insolvency issues, Nigeria is ranked 145 globally and 31 in Africa (Table 2). Evidence seems to suggest that countries with better business rescue regimes have stronger more stable economies, with faster and more successful and sustained recovery rates for insolvent businesses.

$\begin{array}{lcc}\text { Table 1: Ease of Doing Business 2018 World Bank Ranking } \\ \text { Country } & \text { World Ranking } & \text { Africa Ranking } \\ \text { New Zealand } & 1 & \text { NA } \\ \text { Singapore } & 2 & \text { NA } \\ \text { Denmark } & 3 & \text { NA } \\ \text { UK } & 7 & \text { NA } \\ \text { USA } & 8 & \text { NA } \\ \text { Australia } & 15 & \text { NA } \\ \text { Canada } & 20 & \text { NA } \\ \text { Mauritius } & & \\ \text { Rwanda } & 25 & 1 \\ \text { Kenya } & 41 & 2 \\ \text { Botswana } & 80 & 3 \\ \text { South Africa } & 81 & 4 \\ \text { Ghana } & 82 & 5 \\ \text { Nigeria } & 114 & 12 \\ \text { Somalia } & 145 & 21 \\ \end{array}$

Table 2: Resolving Insolvency Issues 2018 World Bank Ranking Country Africa Ranking

$\begin{array}{lc}\text { Mauritius } & 1 \\ \text { South Africa } & 2 \\ \text { Seychelles } & 3 \\ \text { Mozambique } & 4 \\ \text { Cote d'ivoire } & 5 \\ \text { Rwanda } & 6 \\ \text { Botswana } & 7 \\ \text { Kenya } & 12 \\ \text { Nigeria } & 31 \\ \text { Ghana } & 36\end{array}$

The relatively poor ranking of ease of doing business and resolving insolvency issues in Nigeria accounts in part for the high and increasing levels of unemployment, relatively low inflows of foreign direct investment (Figure 3) and slow inclusive economic growth.

As indicated in Figure 4, a comparative review of the equities market of Nigerian, which is characterized by a poor business rescue regime with countries such as USA, UK, South Africa, Australia and Canada with evidently better and more sophisticated business rescue regimes, suggest very strongly that the equities markets of these countries tend to have recovered rather strongly and more quickly than Nigeria, post the global financial crisis. 


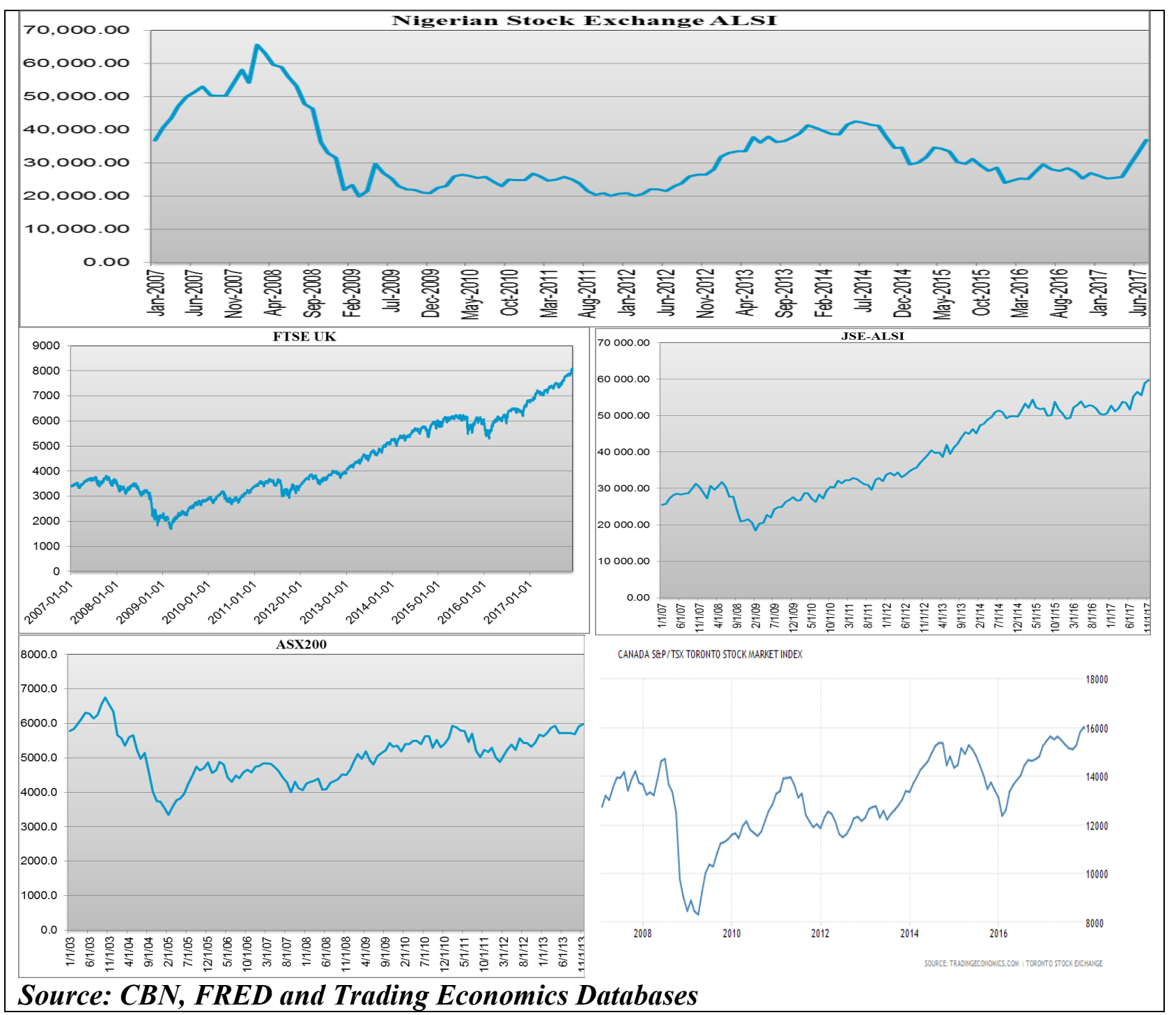

Figure 4: Comparative Stock Market Performance

In addition, Figure 5 shows that countries with better insolvency regimes have relatively fewer and more importantly, a declining rate of bankruptcies and liquidation than countries that do not have robust insolvency and business rescues regimes. From Figure 5, bankruptcies in the USA increased sharply during the US crisis as expected, but declined steadily post-GFC, and have fallen even below the level before the crisis. In the UK also, the post economic crisis is marked by steady and almost immediate reversal of the rate of bankruptcies. Also, in South Africa, without paying attention to the Zuma-effect, there has been a steady decline in bankruptcy after the crisis. These pieces of evidence underscores the need for robust insolvency and business rescue regimes, especially in the light of globalization and its effects, if an economy is to develop steadily and sustainably. 


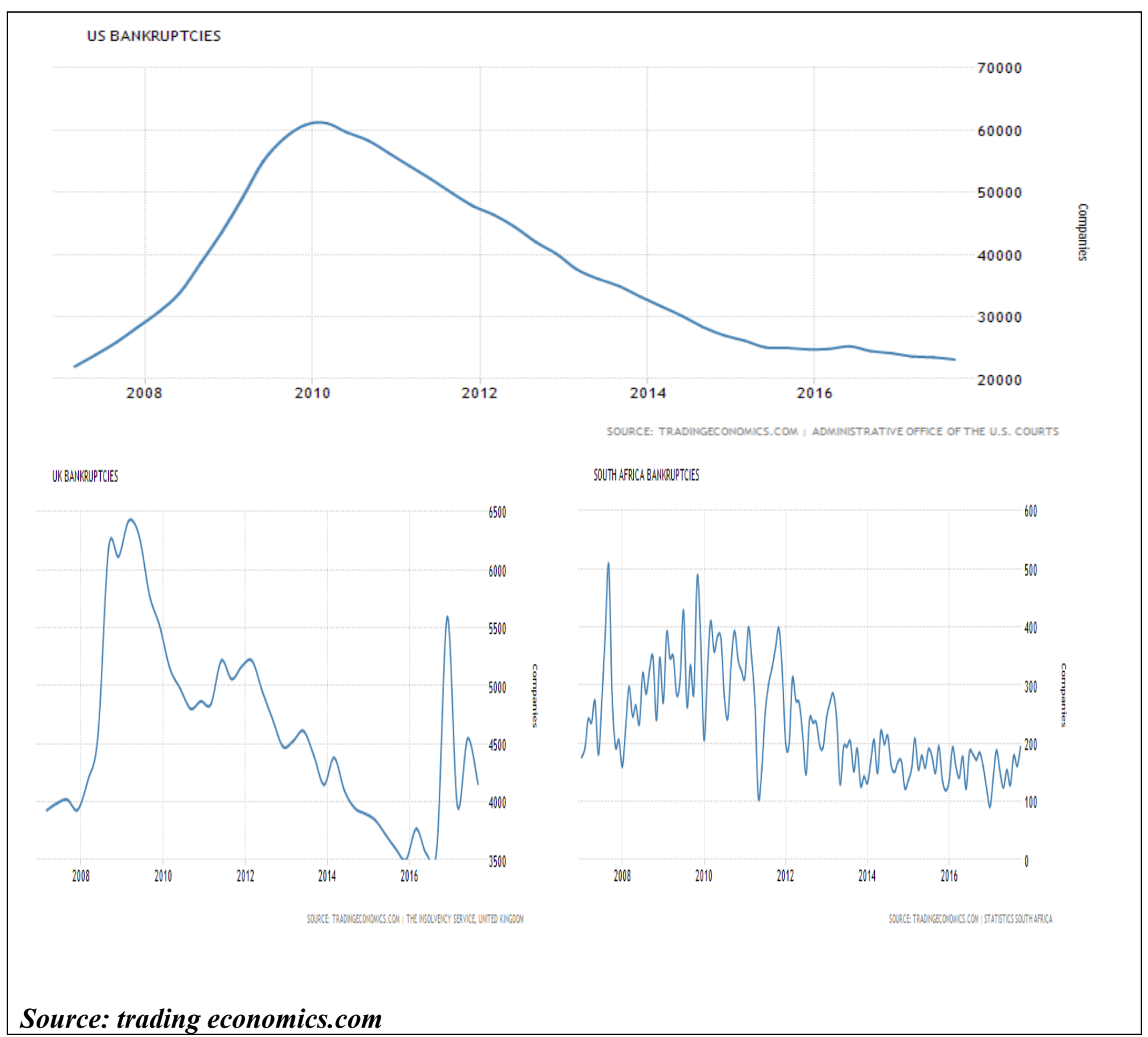

Figure 5: Comparative Bankruptcy Issues

\section{Factors Driving Robust Business Rescue and Insolvency Regimes}

Based on the experience of countries that have institutionalized business rescue and reorganization/restructuring of distressed companies, Table 3 highlights some basic factors or criteria that characterize strong business rescue and insolvency regime and practice. The table presents a comparison of the insolvency practices in Nigeria, USA, UK and South Africa along 10 of these criteria using a scale of; Very High (VH), High (H), Acceptable (A) and Low (L). 


\begin{tabular}{|c|c|c|c|c|c|}
\hline \multicolumn{6}{|c|}{ Table 3} \\
\hline & $\begin{array}{l}\text { Factors / Criteria for Robust Business Rescue and } \\
\text { Insolvency Regime }\end{array}$ & Nigeria & USA & UK & $\begin{array}{l}\text { South } \\
\text { Africa }\end{array}$ \\
\hline 1 & Robustness of enabling legal framework & $\mathbf{L}$ & VH & VH & $\mathbf{H}$ \\
\hline 2 & Frequency of update / improvement in legal framework & $\mathbf{L}$ & $\mathbf{H}$ & $\mathbf{A}$ & $\mathbf{A}$ \\
\hline 3 & Level of awareness of businesses on remedies available & $\mathbf{L}$ & VH & $\mathbf{H}$ & $\mathbf{A}$ \\
\hline 4 & $\begin{array}{l}\text { Level of sophistication and competency of business rescue and } \\
\text { insolvency practitioners (i.e. requirement for certification / } \\
\text { professional affiliation / regulation) }\end{array}$ & $\mathbf{L}$ & A & VH & H \\
\hline 5 & $\begin{array}{l}\text { Speed and capacity of enabling judicial framework / court } \\
\text { process in insolvency }\end{array}$ & L & VH & VH & A \\
\hline 6 & Existence of special insolvency and bankruptcy courts & $\mathbf{L}$ & $\mathbf{H}$ & $\mathbf{H}$ & $\mathbf{A}$ \\
\hline 7 & $\begin{array}{l}\text { Degree of knowledge and competence of judges in business } \\
\text { rescue and insolvency matters }\end{array}$ & $\mathbf{L}$ & H & $\mathbf{H}$ & A \\
\hline 8 & $\begin{array}{l}\text { Alternative dispute (non-litigation) resolution frameworks for } \\
\text { business rescue and insolvency matters }\end{array}$ & $\mathbf{A}$ & $\mathbf{H}$ & H & $\mathbf{A}$ \\
\hline 9 & Regulatory oversight and support & $\mathbf{L}$ & VH & H & $\mathbf{H}$ \\
\hline & Cost of resolution of insolvency issues & VH & $\mathbf{H}$ & $\mathbf{A}$ & $\mathbf{A}$ \\
\hline 11 & Outcome & $\mathbf{L}$ & VH & $\mathbf{H}$ & $\mathbf{A}$ \\
\hline
\end{tabular}

Source: Author's analysis and compilation

From Table 3, it is clear that Nigeria lags the other countries across these criteria, indicating the weak insolvency and business rescue regime in place relative to these other countries.

\section{Insolvency and Business Rescue in the United States of America}

Chapter 7, 11 and 13 are the chapters of the US Bankruptcy Code 1978 that relate to insolvency practice. Chapter 7 of the Bankruptcy Code brings a stop to the operations of the insolvent business and a trustee is appointed to sell the assets and distribute the proceeds to the creditors. The idea of the modern day business rescue was first initiated in the United State of America with Chapter 11 of the Bankruptcy Code 1978. A case filed under this code is frequently referred to as a "reorganization" bankruptcy. The major objective of Chapter 11 of the US code of bankruptcy is defined by the US Supreme Court as (Pretorius \& Rosslyn-Smith, 2014)

In proceedings under the reorganization provisions of the Bankruptcy Code, a troubled enterprise may be restructured to enable it to operate successfully in the future. ... By permitting reorganization, Congress anticipated that the business would continue to provide jobs, to satisfy creditors' claims, and to produce a return for its owners ... Congress presumed that the assets of the debtor would be more valuable if used in a rehabilitated business than if 'sold for scrap'.

Under the Chapter 11 of the Bankruptcy Code, debtors or distressed business are protected against litigation through the imposition of an automatic stay. This prescribes that the creditor is under a moratorium from proceeding to take any legal actions after the debtor has filed for a reorganization of the distressed company. While the automatic stay is in place, the creditors are restricted from taking any legal actions against the business in terms of sales of the asset and property of the business until the case is eventually resolved in the bankruptcy court. This gives room for a distressed company to remain in operation as the management alongside the creditor arrange for a restructuring plan. 
Chapter 11 empowers a trustee to manage the business, which in most cases is the debtor in possession of the company. In case of unreliable or untrustworthy debtor in possession a case trustee is appointed. The trustee is then empowered to restructure the business as it deems fit within the first 120 days. Within this period the trustee can implement any form of favorable capital restructuring that can ensure the revival of the business. The control of the business now belongs to the bankruptcy court, as major decision-making must receive court approval and the debtor in possession remains under the supervision of the US Trustee. The debtor in possession submits report of his operations and the US Trustee monitors applications for compensation and reimbursement by professionals, plans and disclosure statements filed with the court, and creditors' committees. (see Bezuidenhout, 2012; Pretorius \& Rosslyn-Smith, 2014; Conradie \& Lamprecht, 2015). The Chapter 11 as adopted by the US basically empowers the debtor over the creditor (Bezuidenhout, 2012).

\section{Insolvency and Business Rescue in the United Kingdom (England and Wales)}

In United Kingdom Insolvency and Bankruptcy is substantially contained in a single statute. The main sources of law in this regard are the Insolvency Act of 1986, the Insolvency Rule of 1986, the Company Director Disqualification Act 1986, Employment Right Act 1986, Employment Right 1996, Part X11 of the Insolvency Regulations (EC) 1346/ 2000.0ther aspects of law that relate to Insolvency in UK include case laws and Labour related cases (Okolo, 2016:1). The objective of the England Insolvency Act of 1986 was to rehabilitate and help preserve businesses that are faced with financial difficulties by giving it the opportunity to undergo a reorganization process as against the liquidation process of winding up. It provides the distressed company and the creditors alternatives with which insolvency matters are resolved. This can either be by appointment of an Administrator or a Company Voluntary Arrangement (CVA). The Administrator is appointed to manage the business for a period of 12 months. It is saddled with the responsibility of trying to revive the company to make it continue as a going concern and in the case of eventual liquidation, realizing the assets to yield return and distribute among the creditors. Unlike Chapter 11 of the US Bankruptcy Law where the debtor retains the right to manage the business, the British rescue system gives more credence to the creditor as an independent administrator runs the affairs of the business.

The British system further creates and environment for informal arrangement that encourages workout through the company voluntary arrangement. This practically makes reference to the "London Approach" as proposed by the International Association of Restructuring, Insolvency and Bankruptcy Professionals (INSOL). The objective of the company voluntary arrangement is to help revive a financially distress company through a voluntary reorganization / business rescue process before an insolvency charge is filed. It is however observed that this approach has not really been successful given the fact that there is no binding moratorium on the creditor (Pretorius \& Rosslyn-Smith, 2014; Conradie \& Lamprecht, 2015). The Insolvency Act (1986) has been criticized for the excessive importance given to securing the creditors. Overtime reforms have been made as provided by the Enterprise Act of 2002 (Yang \& Li, 2017). The Enterprise Act of 2002 provides for administrative procedures that involve a licensed independent insolvency practitioner that take necessary steps to ensure the going concern of the distressed business (Bezuidenhout, 2012).

\section{Insolvency and Business Rescue in Canada}

In Canada, there is distinction between large and small firms. A company having a debt profile as high as CAN\$5 million is classified as a big company and will file for restructuring under the Companies' Creditors Arrangement Act (CCAA) 1985, while companies with less debt crisis file for restructuring under the Bankruptcy and Insolvency Act (BIA) 1985. Under the CCAA 1985, liquidation is not an alternative (Conradie \& Lamprecht, 2015). Therefore the parties involved 
in the restructuring process must succumb to a restructuring plan (Pretorius \& Rosslyn-Smith 2014). Ever since the promulgation of the two acts, there have been progressive efforts to continue to implement reforms that will update the process of insolvency management.

\section{Insolvency and Business Rescue in Australia}

Under the Australian Corporations Act of 2001, the goal of ensuring business survival goes beyond the going concern of the business. Rather it is to sustain the value of businesses, secure employment and maintain stability in the economy (Bezuidenhout, 2012). Companies as well as the creditor(s) can apply for Voluntary Administration (VA). It follows that there will be an appointment of an administrator independent of the company who has the responsibility of understanding the financial position of the company and propose restructuring plans that will ensure the going concern of the company either by adopting a Deed of Company Arrangement (DOCA) or other appropriate measure, or implement a liquidation process that will yield better returns to the creditors than direct liquidation.

\section{Insolvency and Business Rescue in South Africa (Chapter 6)}

The business rescue regime initiative was first introduce in South African in 2008 by the South African Companies Act (No. 71 of 2008) and the Chapter 6 became operational in the year 2011 (Conradie \& Lamprecht, 2015). According to Bezuidenhout (2012), business rescue related practice was practically based on the Judicial Management Procedure which was as provided by the Companies Act 61 of 1973 and was based on court appointment of a Judicial Manager, a process which had really not yielded positive outcome over the years of practice.

Business rescue, as defined by the South Africa Act of 2008, refers to proceedings which facilitate the rehabilitation of a company that is financially distressed by providing for the temporary supervision of the company and the management of its affairs, business and property, as well as a temporary moratorium on the rights of claimants against the company or in respect of property in its possession (Pretorius \& Rosslyn-Smith, 2014). By so doing, a rescue plan is implemented to restructure the affairs, business, property, debt, other liabilities and equity of the company such that the possibility that the company continues as a going concern is maximized and in situations where that is unachievable, the outcome of the liquidation process yields more return than company's stakeholder creditors or shareholders than the immediate liquidation of the company (Conradie \& Lamprecht, 2015).

Distressed companies in South Africa now have the opportunity to choose from the alternatives of either instigating an official business rescue proceedings, an informal out of court settle in form of a work-out- arrangement or a voluntary liquidation process (Bezuidenhout, 2012). Application for business rescue to the court may be initiated voluntarily by a distressed company or by an affected stakeholder, which does not give room for any form of harassment from the creditors (Conradie \& Lamprecht, 2015). The goal of the process as stipulated by the legislation is to ensure that the company is returned to existence and remains a going concern or the process of realization of assets yield better returns for the company's creditors than the immediate liquidation. Therefore the rescue procedure ensures that an independent and qualified Business Rescue Practitioner (BRP) is appointed and takes full control of the company. The BRP has the responsibility of developing a business rescue plan, which is considered by the stakeholder at the creditors' meeting. The process of business rescue end at the point when the court has set aside the resolution that initiated the rescue process or the process has been completely converted to liquidation or the business rescue practitioner has filed for a notice of termination of business rescue process. 
South African Chapter 6 is different from the Chapter 11 of US Bankruptcy Act. As it is designed, it is modeled in line with the British and Roman-Dutch reorganization of distressed company with the appointment of an administrator to ensure recovery of the firm (Bezuidenhout, 2012). Bradstreet (2011) further noted that South African Companies Act has followed the international insolvency law as it has provide a platform for an informal "workout" or "pre-packaging" administration that makes compromise with creditors whether or not the company is financially distressed or not.

Among other countries that have imbibed the idea of business rescue and implemented reforms that encourage restructuring and reorganization are Germany (1999), Spain (2004), France (2006), Sweden (2010), Belgium (2010), Netherlands (2011), (Wessels, 2015). African countries like Mauritius, Uganda, Kenya to name a few have made progressive moves to redefine their corporate legal framework to inspire business rescue. Carcea et al. (2015) provide evidences on the impact of efficiency in solvency practice on economic indicators in the European Union (EU). They submitted that efficiency in insolvency practices have positive impact on self-employment rate and this process was associated with speed of normalization of the Non-performing Loan rate in the EU.

\section{INSOLVENCY PRACTICE IN NIGERIA}

Insolvency practice in Nigeria is still very basic and with many complexities in business rescue process, which requires improvements (INSOL-WBG, 2016; Nigam \& Boughanmi, 2017). It is observed that as much as the globalization transmits shock to the economy, Nigeria is yet to follow the global trend in placating the effects of such shocks. Unlike the existing state in Nigeria, modern insolvency regulations and practices of advanced countries no longer focus on the liquidation and immediate settlement of creditors, but rather a formal mechanisms of restructuring is implemented to resuscitate and rehabilitation the distressed company (Idigbe, 2011; Pretorius \& Rosslyn-Smith, 2014; Nigam \& Boughanmi, 2017).

In Nigerian the primary legislation for insolvency is the Bankruptcy Act of 2004 and the Company and Allied Matter Act 2004 (Akinwunmi, 2012). As mentioned in Idigbe (2013) the World Bank reports on the observance of standards and codes principles and guidelines for effective insolvency and creditor rights systems, published in October 2007 identified the following weaknesses in Nigerian insolvency law:

1. Lack of efficient means by which debtors can rearrange their affairs and preserve a potentially viable entity

2. Absence of credible legal threat to manage recalcitrant debtors

3. No provisions for insolvency practitioners to be qualified, regulated, licensed or bonded, and

4. Substantially under-resourced court system, which is susceptible to corruption and substantial delay.

The UK Companies Act of 1984 forms the foundation of Nigerian Company and Allied Matters Act (2004) (enacted in 1990), with its provisions for dealing with distressed companies. While the UK Companies Act has been reviewed on several occasions especially on the handling of insolvency and liquidation matters, this has not been the case for the Nigeria. Okoli (2016) noted that the legal framework for insolvency practice in Nigeria is CAMA Part 14, which has to do with Receivership and Manager. Part 15 dictates the winding up of companies, and Part 16 with Arrangement and Compromise. As provided by Section 409 of CAMA, a company is declared insolvent if:

1. The company is indebted to a sum exceeding $\mathrm{N} 2,000$ (about $\$ 6.00$ ), and there has been a demand and failure to pay within 21 days of the demand; or 
2. The execution of a court judgment or order in favor of a judgment creditor is returned partially or wholly unsatisfied; or

3. The courts, after taking into account any contingent or prospective liability of the company is satisfied that the company is unable to pay its debts.

The fact that insolvency is basically the inability of a company to meet its obligations to its creditor does not seem to be a clear cut definition of corporate insolvency and personal bankruptcy as it only requires a court injunction to proclaim insolvency (Idigbe, 2009). Moreover, the position of the presiding Judges mostly do not have financial know how to properly understand the bank statement and often follow the law to the letter. Therefore, an observed process of business recovery cannot be identified.

Unlike the other countries discussed here that have special requirements for the appointment of an administrator or a trustee, the requirement for the appointment of Receiver in Nigeria is based on Part 14 Section 387(1) which stated the set of people that cannot be appointed as a Receiver/Manager (Okoli, 2016). This section of the law suggests that just about anybody can be a Receiver so long he/she is not an infant, a person of unsound mind, a corporate body, an un-discharged bankrupt, a director or auditor of the company or any person convicted of offences involving fraud which might make way for the appointment of inexperienced person (Okoli, 2016).

The insolvency practice in Nigeria as provided gives preference to secured credit holders who have direct claims on the asset of the company, the cost associated with administration of insolvency (receivership/winding-up/liquidation) and other government levies (Idigbe, 2009). It is evident that there is wide gap between the practice of insolvency and business rescue globally and the reality in Nigeria.

\section{Business Rescue Practice Reforms In Nigeria}

In Nigerian the Company Voluntary Arrangement is given effect via a court sanctioned "Scheme of Arrangement". It is governed by Companies and Allied Matters Act CAP 20 LFN, 2004, specifically sections 537, 538, 539 and 540. Sections 537 of the Act defines an "arrangement" as "any change in the rights or liabilities of members, debenture holders or creditors of a company or any class of them, or in the regulation of a company, other than a change effected under any other provision of this Act or by the unanimous agreement of all parties affected thereby". The procedure follows that;

- An application is made to the court, asking it to call a meeting between the company and its creditors or a class of creditors

- The scheme of arrangement / reconstruction is put to the meeting and a vote is taken

- If there is $75 \%$ in value and including proxies in favor, the court will be asked to sanction it

- If the court sanctions it, the scheme is binding on all the creditors

This puts the company at risk of closure if the $75 \%$ is not reached and at the mercy of the creditor(s). In order legal jurisdictions, Administrative orders (UK) [Chapter 11 - Bankruptcy protection (USA)], were introduced to allow a company time and protection from its creditors, so as to put a recovery plan in place.

Reasonable efforts have been made with the banking sector to ensure survival. The Asset Management Corporation of Nigeria (AMCON) Act No 4 of 2010 (as amended in 2015) provides a breathing space for the management of insolvency in the banking sector. This perhaps is as a 
result of the systemically critical nature of the banking sector. However, the AMCON Act 2010 had been leveled with criticisms following the perceived highhandedness of the powers given to AMCON without proper considerations for the stakeholders in the distressed company as ownership of all banks asset is diverted to AMCON without any restrictions (Omoregie, 2017).

The Central bank of Nigeria (CBN) and the Nigerian Deposit Insurance Commission (NDIC) have made significant effort to create a legal framework and regulations to help distressed banks manage insolvency issues through the processes of restructuring, consolidations, mergers and acquisitions, recapitalization and liquidation where such proves to be the best option. (see Omoregie, 2017). The CBN is empowered by the Banks and Other Financial Institutions Act (BOFIA) 2004 not only to regulate the banking sector but also to takeover and manage banks facing financial difficulties. The Failed Bank (Recovery of Debts) and Financial Malpractices in Bank Act, 2004 (as amended) provides a legal framework that ensures safe and sound financial practice by punishing financial offenders and recovery of debt owed to distressed banks. Olukotun et al. (2013) provided evidence that the improvement in deposit cover by NDIC has had positive effect on depositors' confidence in the banking system..

Recently, in further recognition of effect of declining commodity prices, on the risk exposure of the banking sector, most especially to the oil sector, the CBN established the Private Asset Management Companies (PAMCs) in accordance with the Exposure Draft of the Framework for Licensing, Regulation and Supervision of the Business of Private Asset Management Companies in Nigeria. The PAMCs are licensed to manage the non-performing loans within the banking industry that might ensue as a result of falling commodity prices that affect the risk assets. Therefore, the PAMCs will work in place of AMCON to acquire, manage and dispose-off banks and other financial institutions' asset in periods of distress. They are set up to further provide consultancy and advisory services to banks and other financial institutions.

As a result of some of these on-going reforms, the World Bank Data on Doing Business has revealed that Nigeria has moved up the rank in terms of ease doing business from 169 in 2017 ranking to 145 in the 2018 ranking which is also reflected in some other indicators. The Presidential Enabling Business Environment Council (PEBEC) was set up in July 2016, to eliminate all forms of bureaucratic constraints to successful running of business activities in Nigeria from startup, growth to sustenance. It is established as an intergovernmental and ministerial council chaired by the Vice President and comprise of the National Assembly, ministries, departments and agencies (MDAs), representatives from Lagos, Kano and the private sector. Policies and reform agenda of PEBEC are transmitted through the Enabling Business Environment Secretariat (EBES). Overtime, two different National Action Plans have been implemented to foster the objectives of PEBEC. The EBES has identified 7 priority reform areas: starting a business, getting credit, trading across borders, getting electricity, dealing with construction permits, paying taxes and registering property. The National Action Plans were designed to ensure that the ease of doing business reforms extend to all MDAs within a year in order to increase productivity in the country. Further reference to the success of PEBEC, Nigeria moved two steps up the rank from 127 to 125 in the World Economic Forum's Global Competitiveness Index (GCI) for 2017-2018.

However much stride has been made to ease doing business, the legal framework is still very unsupportive of business rescue in the practice of insolvency. The World Bank Doing Business Data also revealed that Nigeria has not made any progress in terms of resolving insolvency issues, but rather dropped from 140 in the 2017 ranking to 145 in 2018. However, the Federal Government alongside the National Assembly have made progress in sponsoring an Omnibus Legislation on Business rescue to consolidate efforts on ease of doing business. 
Insolvency practitioners under the auspices of the Business Recovery and Insolvency Practitioners Association of Nigeria (BRIPAN) have been creating awareness, collaborating and providing advisory services to creditor and borrowers in order to ensure insolvency practice in Nigeria is done in good faith for the benefit of all involved. In a bid to create a legal framework and acceptability of business rescue in insolvency practice, BRIPAN has further intensified effort by moving for a reform agenda and has produced a Draft Insolvency Bill. The proposed bill has passed through the various concerned ministries and has been approved by the Ministry of Justice for the Federal Executive Council order, therefore waiting to be passed to law. BRIPAN further intensifies its efforts as it pursued international exposure for its members through increased participation in INSOL and United Nations Commission on International Trade Law (UNCITRAL) meetings, conferences and fellowships, and active engagement of its leaders with international experts. It also inaugurated its own international conference. BRIPAN achieved observer status at UNICITRAL Group V on Insolvency in 2012 (Idigbe, 2013).

\section{Bringing Nigeria into the "Modern Age"}

While some progress has been made in improving ease of doing business in Nigeria and improving the effectiveness of the process, practice and legal framework for business rescue and insolvency practice in Nigeria, much still needs to be done. Table 4 below is a summary of some recommendations for improving the business rescue and insolvency regime in Nigeria.

\begin{tabular}{|c|c|c|}
\hline \multicolumn{3}{|c|}{ Table 4} \\
\hline \multicolumn{3}{|r|}{ Nigeria - Required Action } \\
\hline 1 & Robustness of enabling legal framework & $\begin{array}{l}\text { Pass relevant legislation to consolidate and improve } \\
\text { business rescue and insolvency practice (i.e. BRIPAN } \\
\text { Sponsored Bill + Proposed amendment to CAMA) }\end{array}$ \\
\hline 2 & $\begin{array}{l}\text { Frequency of update / improvement in } \\
\text { legal framework }\end{array}$ & $\begin{array}{l}\text { Regular update / amendment of legislation in line with } \\
\text { emerging trends }\end{array}$ \\
\hline 3 & $\begin{array}{l}\text { Level of awareness of businesses on } \\
\text { remedies available }\end{array}$ & Public enlightenment and advocacy \\
\hline 4 & $\begin{array}{l}\text { Level of sophistication and competency } \\
\text { of business rescue and insolvency } \\
\text { practitioners (i.e. requirement for } \\
\text { certification / professional affiliation / } \\
\text { regulation) }\end{array}$ & $\begin{array}{l}\text { Mandatory certification / licensing of Business Rescue and } \\
\text { Insolvency Practitioners }\end{array}$ \\
\hline 5 & \begin{tabular}{|l|} 
Speed and capacity of enabling judicial \\
framework / court process in insolvency
\end{tabular} & $\begin{array}{l}\text { Establish special bankruptcy courts / Advocate for ADR / } \\
\text { Multi-creditor workout approaches (non-litigious) }\end{array}$ \\
\hline 6 & $\begin{array}{l}\text { Existence of special insolvency and } \\
\text { bankruptcy courts }\end{array}$ & Establish special bankruptcy courts \\
\hline 7 & $\begin{array}{l}\text { Degree of knowledge and competence of } \\
\text { judges in business rescue and insolvency } \\
\text { matters }\end{array}$ & $\begin{array}{l}\text { Regular training of Judges in business rescue and } \\
\text { insolvency laws and practice (BRIPAN Initiative) }\end{array}$ \\
\hline 8 & $\begin{array}{l}\text { Alternative dispute (non-litigation) } \\
\text { resolution frameworks for business } \\
\text { rescue and insolvency matters }\end{array}$ & $\begin{array}{l}\text { Establish special bankruptcy courts / Advocate for ADR / } \\
\text { Multi-creditor workout approaches (non-litigious) }\end{array}$ \\
\hline 9 & Regulatory oversight and support & ICAN/BRIPAN / SEC etc. \\
\hline 10 & Cost of resolution of insolvency issues & \\
\hline 11 & Outcome & Results from implementing all of the above \\
\hline
\end{tabular}




\section{CONCLUSION}

The link between strong business rescue and insolvency regimes and business survival and economic development has been well supported by evidence in the literature. The impact of globalization on economies is also obvious. Nigeria still lags behind other developing and developed countries in putting in place robust business rescue and insolvency regimes that meets global best practice. This has resulted in a less than optimal business environment, low level of business confidence by foreign investors, low FDI inflows, high level of business failures and high unemployment. Despite some ongoing attempts at reforms, this paper argues for more comprehensive and faster paced reforms of the business rescue and insolvency laws and regulations, professionalisation of business rescue practice and improvement in ease of doing business, in line with global best practice and in response to the imperatives of globalization.

\section{Reference}

Bankruptcy and Insolvency Act. (2017, August 30). In Wikipedia, The Free Encyclopedia. Retrieved 14:15, November 17, 2017, from https://en.wikipedia.org/w/index.php?title=Bankruptcy and Insolvency Act\&oldid=798057989

Barnard, H. (2016). A Comparison between Business Rescue in South Africa and Voluntary Administration in Australia

Bezuidenhout, P. (2012). A review of business rescue in South Africa since implementation of the Companies Act (71/2008). A MBA Mini-dissertation submitted to the North-West University, Potchefstroom Campus.

Bradstreet, R. (2011). The new business rescue: Will creditors sink or swim? South African Law Journal, 128(2), $352-380$.

Brouwer, M. (2006) Reorganization in US and European Bankruptcy law. European Journal of Law and Economics, $22,5-20$.

Carcea, M. C., Ciriaci, D., Lorenzani, D., Pontuch, P., \& Cuerpo, C. (2015). The Economic Impact of Rescue and Recovery Frameworks in the EU (No. 004). Directorate General Economic and Financial Affairs (DG ECFIN), European Commission.

Companies' Creditors Arrangement Act. (2017, August 11). In Wikipedia, The Free Encyclopedia. Retrieved 14:09, November 17, 2017, from https://en.wikipedia.org/w/index.php?title=Companies\%27 Creditors Arrangement Act\&oldid=795031972

Conradie, S. \& Lamprecht, C. (2015). Business rescue: How can its success be evaluated at company level? Southern African Business Review, 19(3), 1 - 29.

Epeoglou, M. T. (2017). The Recast European Insolvency Regulation: A Missed Opportunity for Restructuring Business in Europe. UCL Journal of Law and Jurisprudence, 6(1), 31-59.

Herbert Nnamdi Okoye, H. N. \& Nwaigwe, L. C. (2015). The impact of globalization to business and the world economy. International Journal of Business and Management Review, 3(.5), 17 - 32.

Idigbe, A. 1. (2009). The Nigerian Insolvency Law and the right of creditors and Account holders of intermediated Security vis a vis the insolvent intermediary being a paper delivered at SEC on Unidroit workshop on intermediated securities held in Nigeria in May 2009.

Idigbe, A. 1. (2011). Driving business recovery: the role of the courts. Insolvency \& Restructuring - Nigeria.

Idigbe, A. 1. (2013). Progress of insolvency law reform. Insolvency \& Restructuring - Nigeria

INSOL \& WBG 2016. Freedom to Fail? Insolvency for Micro, Small and Medium Enterprises. Africa Round Table 67 October 2016

INSOL Statement of Principles for a Global Approach to Multi-Creditor Workouts. Retrieved from http://murrayslegal.com.au/blog/2017/05/10/insols-statement-of-principles-for-a-global-approach-to-multicreditor-workouts/

Insolvency Law in Nigeria. Posted by InvestAdvocate on October 11, 2016 in Uncategorized. http://investadvocate.com.ng/2016/10/11/insolvency-law-nigeria/

Nairametrics, AMCON Sale of Keystone Bank, Retrieved January 212019 from https://nairametrics.com/2018/06/06/acquisition-of-keystone-bank-boosts-amcons-2017-performance/ 
Nathan, B. \& Horn, E. (2009). Demystifying Chapter 15 of the Bankruptcy Code. The Publication for Credit and Finance Professionals, 1 - 5.

Ngwube, A. \& Ogbuagu, M. (2014). Global Financial Crisis and Nigeria Economy. Global Journal of Management and Business Research, 14(4), 25 - 30.

Nigam, N. \& Boughanmi, A. (2017). Can innovative reforms and practices efficiently resolve financial distress? Journal of Cleaner Production, 140, 1860 - 1871.

Okojie, E. A. (2015) Global company crisis- how effective is the merger solution in Nigeria. Global Journal of Politics and Law Research, 3(2), 93 - 109.

Olukotun, G. A., James, O. O., \& Olorunfemi, K. (2013). Bank Distress in Nigeria and the Nigeria Deposit Insurance Corporation Intervention. Global Journal of Management and Business Research Finance, 13(8), 50-60.

Omoregie, O. K. (2017). Future of Globalization: Awareness and Orientation. What Is the Future of Globalization? Global Network Perspectives. May 01, 2017 http://gnp.advancedmanagement.net/article/2017/05/futureglobalization-awareness-and-orientation

Omoregie, O. K. (2017). Promoting Multi-Creditor Workouts: A Nigerian Perspective. Arabian Journal of Business Management Review, 7(303), 2.

Pretorius, M., \& Rosslyn-Smith, W. (2014). Expectations of a business rescue plan: international directives for Chapter 6 implementation. Southern African Business Review, 18(2), 108-139.

Schoenberg R, Collier N, Bowman, C. (2013). Strategies for business turnaround and recovery: a review and synthesis. European Business Review, 25: 243 - 262.

Soh, A. (2007). Chapter 15 of the US Bankruptcy Code: An Invitation to Forum Shopping? (Doctoral dissertation, Harvard Law School).

Wessels, B. (2015). Business Rescue in Insolvency Law - Changing the laws and challenges for the profession.

Winer, P., Levenstein, E. \& Barnett, L. 2008. Business Rescue: a Novel Feature of the New South African Companies Act 71 of 2008. Pretoria: Werksmans Attorneys.

Xie, B. (2016). Comparative Insolvency Law: The Pre-pack Approach in Corporate Rescue. Edward Elgar Publishing.

Yang, M. \& Li, X. (2012).The History of Corporate Rescue in the UK. Asian Social Science, 8(13), 21 - 28. 